\title{
On-Line Engineering Education with Emphasis on Application of Bloom's Taxonomy
}

\author{
K L Chugh ${ }^{1}$, B MADHURAVANI ${ }^{2}$ \\ ${ }^{1,2}$ Department of CSE, \\ MLR Institute of Technology, \\ Dundigal, Hyderabad-500043 \\ ${ }^{1} \mathrm{kl}$ chugh@hotmail.com \\ ${ }^{2}$ madhuravani.peddi@gmail.com
}

Education. The Online Engineering education coupled with Chalk and Talk method will allow the implementation of all levels of Bloom's Taxonomy in the Engineering curriculum thus fulfilling the objectives of OBE can be possible.

Keywords: Outcome Based Education, Bloom's Taxonomy, Chalk and Talk, E-learning and Learning Skills.

\section{Introduction}

The Outcome Based Education mandates the inclusion of Bloom's Taxonomy in the Teaching-Learning process relevant to the Engineering curriculum. There are six levels of Bloom's Taxonomy as shown in Figure 1:

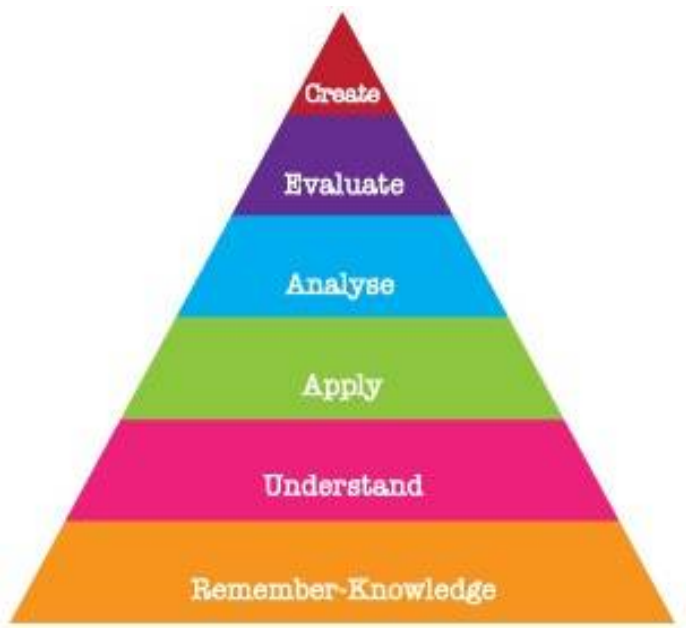

Figure 1: Six Levels of Bloom's Taxonomy

Definition of the different levels of thinking skills in Bloom's Taxonomy [4] is given below:

1. Remember - recalling relevant terminology, specific facts, or different procedures related to information and/or
Department of CSE,

MLR Institute of Technology, Hyderabad. 
course topics. At this level, a student can remember something, but may not really understand it.

2. Understand - the ability to grasp the meaning of information (facts, definitions, concepts, etc.) that has been presented.

3. Apply - being able to use the previously learned information in different situations or in problem solving.

4. Analyze - the ability to break information down into its component parts. Analysis also refers to the process of examining information in order to make conclusions regarding cause and effect, interpreting motives, making inferences, or finding evidence to support statements/arguments.

5. Evaluate - being able to judge the value of information and/or sources of information based on personal values or opinions.

6. Create - the ability to creatively or uniquely apply prior knowledge and/or skills to produce new and original thoughts, ideas, processes, etc. At this level, students are involved in creating their own thoughts and ideas.

The teaching of the course using only the "Chalk and Talk" method does not afford enough time to implement all levels of the Bloom's Taxonomy. Out of five sessions per week allocated to teach a course, four sessions are earmarked for the teaching theory and one session is reserved for the tutorial. During the theory sessions, the teacher is aiming to complete the syllabus, wherein the focus is only on the first two levels of Bloom's Taxonomy (low-order learning skills). The teacher spends only one session per week on tutorial, wherein problems are solved, thus applying the level 3 of Bloom's Taxonomy. The teachers are unable to implement levels 4,5 and 6 of Bloom's Taxonomy, called the critical Thinking/higher orders skill, in the present scenario of teaching using only the "Chalk and Talk" method. The students are thus being denied exposure to critical Thinking/Higher order skills due to non-implementation of Levels 4,5 and 6 of Bloom's Taxonomy in the curriculum. As a result of this, two important outcomes viz 1) An ability to analyze complex engineering problems (Level 4) and evaluation of alternative solution to select the best (Level 5) and an ability to create (design) a new and original thoughts, ideas, processes, etc (Level 6), are being adversely impacted.

The present method of teaching ("Chalk and talk") needs to be complimented with On-line Education in Engineering colleges. The On-line Education along with Chalk and Talk method will allow the implementation of all six levels of Bloom's Taxonomy in the Engineering curriculum. This will have profound impact in achieving the students learning outcomes as defined in Outcome based Education (OBE).
This paper proposes a model for On-line Engineering education, which can be implemented in the Engineering Colleges, including the one in which the author himself is a teacher.

\section{Mapping Bloom's Taxonomy with Program Outcomes}

The National Board of Accreditation stipulates that every programme of study must have specified "Learning Outcomes", which the students are expected to acquire at the end of the selected programme. Every institution adopts a number of Teaching methodologies and Assessment methods in order to achieve these Learning Outcomes. The adoption of Bloom's Taxonomy in the Teaching Learning Process is one such methodology which has been found to be effective in fulfilling the expected cognitive Learning Outcomes. Faculty members must choose to incorporate the Bloom's Taxonomy in the design of their course description. The importance of Bloom's Taxonomy is highlighted by drawing the matrix which shows the mapping (relationship) of its six levels with the Programme Outcomes. The mapping is illustrated in

Table 1.

\begin{tabular}{|c|c|}
\hline Programme Outcomes & Bloom's Taxonomy \\
\hline $\begin{array}{l}\text { Engineering Knowledge } \\
\text { (Apply) }\end{array}$ & $\begin{array}{l}\text { - Remembering } \\
\text { - Understanding } \\
\text { - Applying }\end{array}$ \\
\hline Problem analysis & $\begin{array}{l}\text { - Remembering } \\
\text { - Understanding } \\
\text { - Analyzing }\end{array}$ \\
\hline $\begin{array}{l}\text { Design / development of } \\
\text { solutions }\end{array}$ & $\begin{array}{l}\text { - Remembering } \\
\text { - Understanding } \\
\text { - Applying } \\
\text { - Creating }\end{array}$ \\
\hline $\begin{array}{l}\text { Conduct investigations of } \\
\text { complex problems }\end{array}$ & $\begin{array}{l}\text { - Analyzing } \\
\text { - Evaluating } \\
\text { - Creating }\end{array}$ \\
\hline Modern tool usage & $\begin{array}{l}\text { - Applying } \\
\text { - Analyzing } \\
\text { - Creating }\end{array}$ \\
\hline
\end{tabular}




\begin{tabular}{|c|c|}
\hline Programme Outcomes & Bloom's Taxonomy \\
\hline The engineer and society & $\begin{array}{l}\text { - Understanding } \\
\text { - Applying }\end{array}$ \\
\hline $\begin{array}{l}\text { Environment and } \\
\text { sustainability }\end{array}$ & $\begin{array}{l}\text { - Understanding } \\
\text { - Applying }\end{array}$ \\
\hline Ethics & $\begin{array}{l}\text { - Understanding } \\
\text { - Applying }\end{array}$ \\
\hline Individual and team work & - Analyzing \\
\hline Communication & $\begin{array}{l}\text { - Understanding } \\
\text { - Analyzing } \\
\text { - Creating }\end{array}$ \\
\hline $\begin{array}{l}\text { Project management and } \\
\text { finance }\end{array}$ & $\begin{array}{l}\text { - Remembering } \\
\text { - Understanding } \\
\text { - Applying } \\
\text { - Evaluating }\end{array}$ \\
\hline Life - long learning & $\begin{array}{l}\text { - Applying } \\
\text { - Analyzing } \\
\text { - Evaluating } \\
\text { - Creating }\end{array}$ \\
\hline
\end{tabular}

Table 1: Mapping Bloom's Taxonomy with Program Outcomes

\section{Classical System of Teaching V/S on-line education}

Classical system of Chalk and Talk method of teaching has been in existence since inception. Though the Chalk and Talk method of teaching has its own advantage, it is not inclusive. The application of alternative method of teaching along with this method will make it more effective. All online study programs are mainly text based and static in content. The efficacy of on-line study programs can be improved by inclusion of dynamic content in addition to the static content.

On line education [5] refers to instructions in a learning environment where teachers and students are away time or space or both and the teacher provides course content through course management application, multimedia resources, the internet, video conferencing, etc. Students receive the content and communicate with the teacher via the same technology. It is normally for distance learning and is called On-line Learning. It is also used in conjunction with face-to-face (Class Room) teaching and is called Blended Learning. As per Luskin, [6] one of the pioneers of E-learning, "e" should be interpreted to mean:

- Exciting

- Excellent

- Extended

- Education

\section{Goals of On-line Education}

The goals of On-line Education are:

a) Information-based content

b) Performance-based content

\subsection{Information-Based Content}

The Information-Based Content communicates information to the students. It is also called ComputerBased-Learning (CBL). The use of computer is a key element in education. In this method, no special skills are learned. All theory lesions be information-based content (Level 1 and Level 2).

\subsection{Performance-Based Content}

Performance-based content helps the student to perform the specific tasks. It is also called Computer-Based Training (CBT). The lesson builds off a procedure skill, which expects students to increase proficiency. All tutorials (Level 3) and Levels $4,5 \& 6$ of Bloom's Taxonomy will be performance based content.

\section{On-line Engineering Education Framework}

Frame work components are:
1) Pedagogy
2) Process
3) People
4) Content
5) Technology

5.1 Pedagogy

The Pedagogy elements are structure or units of educational material:

- Lessons

- Assignments

- Multiple choice questions

- A Quiz

- A Case Study

\subsection{Process}

A set of activities to be carried out within a stipulated time frame to achieve the goals of on-line education. The activities convert the Pedagogy elements into reusable and Standard Learning Objects called metadata. Metadata 
objects are often stored in XML file. It is proposed to use SCORM (Shareable Content Reference Model), which is a de-facto standard for E-learning.

\subsection{People}

All stakeholders constitute people those include subject teacher, subject experts, students, computer specialist and management.

\subsection{Content}

The content constitutes the reusable, standard objects and Tools used to create these objects. The PPTs prepared by the faculty should be converted to the standard Learning objects using the tools.

\subsection{Technology}

The technology consists of three components i.e Audio, Video and Data. Audio consists of streaming video and audio tapes. The data has CBT content (CD-ROM) or delivered over network, computer files and on-line.

\section{Implementation}

The implementing of On-line Engineering Education is proposed in three phases. The implementation can be completed in around 12 to 18 months with each phase spanning 4 to 6 months.

\subsection{Phase-I}

The tasks to be carried out in Phase I are given below:

a) Compilation of course materials in the standard format of PPTs.

b) Editing of PPTs by the expert group

c) E-mailing the PPTs to the students.

d) Stocking the PPTs in the Library.

\subsection{Phase-II}

The tasks in Phase II are described below:

a) Launching of PPTs on the college web server.

b) Class room teaching using PPTs and Interactive white board.

c) Conversion of Course materials to learning objects as defined in SCORM.

\subsubsection{Proposed model for Static and Dynamic content for} Phase II

The model is intended to provide lecture content both static and dynamic to the student/audience. The static content includes PPTs slides and the dynamic content consists of instructor's spoken words (Audio), facial expression (Video) and the hand-written explanation on the touch screen (Text). It has also the feature for on-line voice chat with the instructor at the end of the lecture for doubt clearance. It also has the capability to store the complete lecture content on the server data base for later use, such as downloading by the students on his/her I-Pods and desk tops. Architecture with process flow is shown in Figure 2.

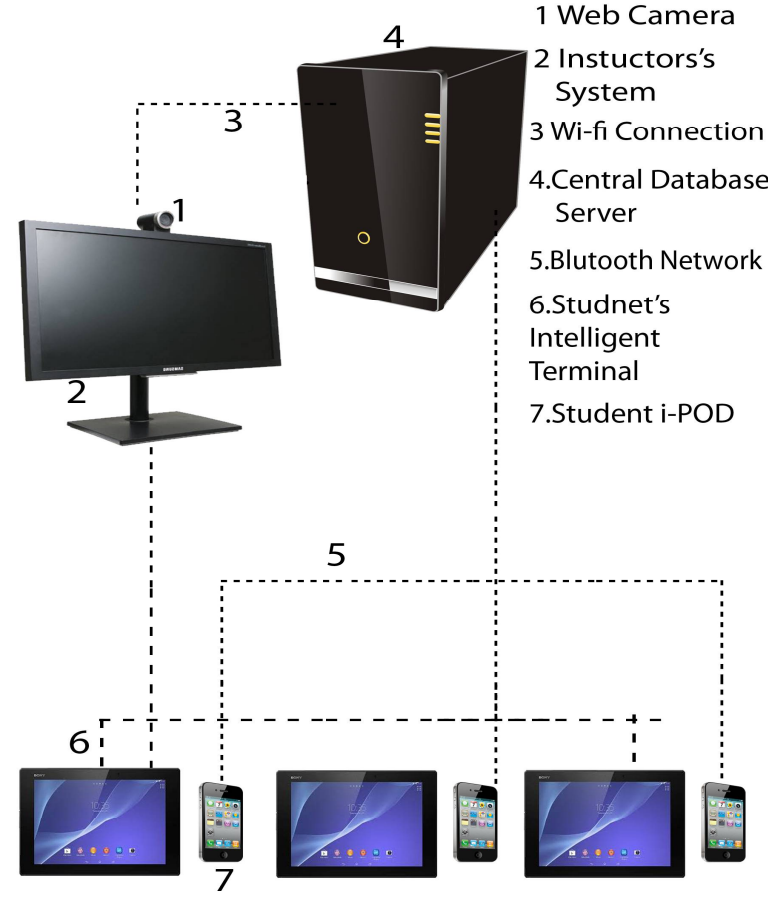

Figure 2: Architecture

The Instructor system consists of a laptop with touch screen and stylus for hand writing. The instructor loads the today's lecture PPTs to his system. The student intelligent systems are connected and synchronized to the instructor system via Wi-Fi. As the instructor displays a PPT, the same PPT is displayed to the student's intelligent terminals. The video and audio of instructor during the course of his explanation on the PPT is captured and transmitted live to the student's intelligent terminals. The instructor has the facility to explain the PPT by writing on the touch screen using the stylus. Handwritten scripts are converted into typed text and will be displayed on the student's intelligent terminals.

The Learning System has the feature to store while streaming the lecture contents both static and dynamic on to the Server database for later use. The student has the facility of using his I-POD to download the today's lecture content at the end of the lecture. Student can play the I-Pod at his own convenience to recapitulate the today's lecture and also can create the course material by combining the every day's lectures for his study during examination and future use in his career $\&$ for his future support.

The model can be further expanded to Virtual Class Room employing the facility of internet and video conferencing. The expanded model can be used in Phase III.

\subsection{Phase-III}

The tasks in Phase III are: 
a) Video conferencing of Teaching-Learning Content

b) Creation of Virtual Learning Environment (VLE)

\section{Result: The Application of Bloom's Taxonomy at} MLR Institute of Technology, Hyderabad.

The application of Bloom's Technology has been included in the Course Curriculum of MLR Institute of Technology, Dundigal, Hyderabad commencing w.e.f the Academic Year 2014-15. Faculty members are designing the course material in order to provide all students with the opportunity to gain knowledge of different types of thinking skills as defined in the Bloom's Taxonomy. The evaluation methods to assess the Learning Outcomes are mid-term and End Examinations. The question papers designed by the faculty members were compared with the six levels of Bloom's Taxonomy. The analysis showed that most of the questions pertain to the first three levels viz Level 1, Level 2 and Level 3. As an example, the analysis of Engineering Physics subject for $1^{\text {st }}$ year is shown in Figure 3, 4, 5 and 6.

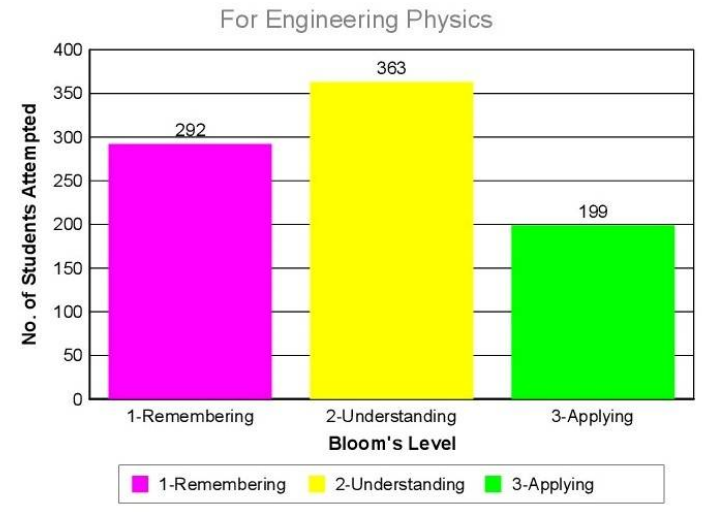

Figure 3. No. of Students Attempted/Bloom's Levels
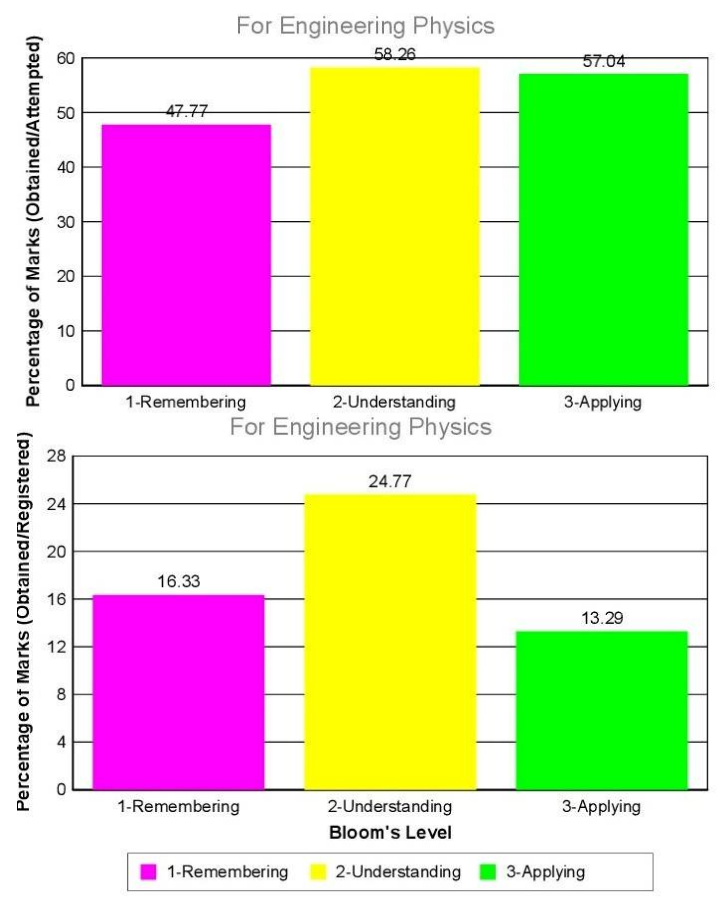

Figure 4. Percentage of Marks (Obtained/Attempted) Bloom's Levels

Figure 5. Percentage of Marks (Obtained/Registered) Bloom's Levels

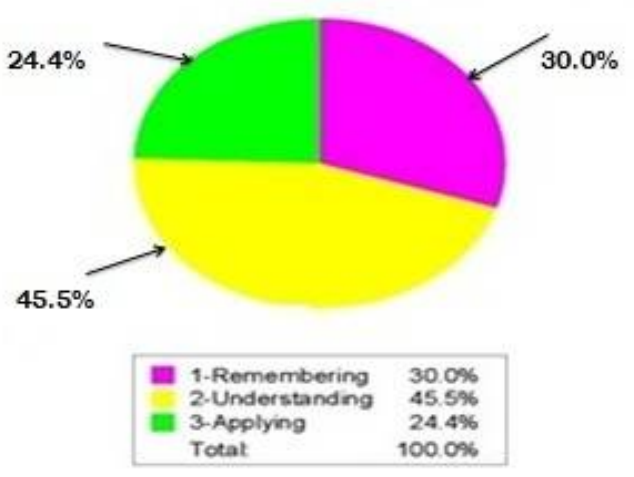

Figure 6. Application of Bloom's Levels

The question papers pertaining to other subjects gave similar results as depicted for Engineering Physics.

The results as shown above indicate that the faculty members have implemented the first three levels of the Bloom's Taxonomy. They are in the process of implementing the next three levels viz Level 4, 5 and 6 (called critical thinking skills) in their curriculum.

\section{Outcome of the On-line Engineering Education}

The implementation of the On-line Education ensures that the study material for the course has been provided to students on-line. In such a situation, there is no need to keep four sessions per week for theory out of five sessions earmarked in the time-table of a specified course. Since the material is being provided to the students on-line, two sessions are considered enough to cover the syllabus which was originally supposed to be completed in four sessions. Two sessions thus saved can be used to implement Levels 4, 5 and 6 of Bloom's Taxonomy. The outcome of On-line Engineering Education thus allows distribution of five sessions per week as follows:

a) Two sessions for theory (Level 1 and 2 of Bloom's Taxonomy)

b) One session for Tutorial (Level 3)

c) One session for Analysis and Evaluation exercises (Levels 4 \& 5 respectively)

d) One session for creative thinking (Level 6).

The comparison showing the distribution of five sessions per week between the present method of teaching (Chalk \& Talk) and the proposed method of teaching (On-line Education) is shown in Table 2. 


\begin{tabular}{|c|c|c|c|c|}
\hline \multirow[b]{2}{*}{ Item } & \multicolumn{2}{|c|}{$\begin{array}{l}\text { Present method of } \\
\text { teaching } \\
\text { (Chalk \& Talk) }\end{array}$} & \multicolumn{2}{|c|}{$\begin{array}{l}\text { Proposed method } \\
\text { of teaching } \\
\text { (On-line } \\
\text { Education) }\end{array}$} \\
\hline & $\begin{array}{c}\text { No. of } \\
\text { session } \\
\text { s }\end{array}$ & $\begin{array}{l}\text { Applicapabi } \\
\text { lity of } \\
\text { Bloom's } \\
\text { Taxonomy }\end{array}$ & $\begin{array}{c}\text { No. } \\
\text { of } \\
\text { sessio } \\
\text { ns }\end{array}$ & $\begin{array}{c}\text { Applica } \\
\text { ability } \\
\text { Bloom's } \\
\text { Taxono } \\
\text { my }\end{array}$ \\
\hline Theory & 4 & $\begin{array}{c}\text { Levels } \\
1 \& 2\end{array}$ & 2 & $\begin{array}{c}\text { Levels } 1 \\
\& 2\end{array}$ \\
\hline Tutorial & 1 & Level 3 & 1 & Level 3 \\
\hline Analysis & 0 & \multirow{3}{*}{$\begin{array}{c}\text { Levels } 4,5 \\
\& 6 \text { could } \\
\text { not be } \\
\text { implemente } \\
\text { d }\end{array}$} & \multirow[b]{2}{*}{1} & Level 4 \\
\hline $\begin{array}{l}\text { Evaluati } \\
\text { on }\end{array}$ & 0 & & & Level 5 \\
\hline Creation & 0 & & 1 & Level 6 \\
\hline
\end{tabular}

Table 2: Comparison between the present method of teaching and proposed method of Teaching

\section{Conclusion}

Outcome based education necessitates the implementation of all six levels of Bloom's Taxonomy in the Teaching-Learning Process. The six levels can be implemented effectively if the present system of Chalk and Talk method of teaching is complimented with the On-line Engineering Education as brought out under Out-come in para 8 of the paper. On-line Education, which has already been adopted by many institutions, is the need of the hour and should be accepted as standard practice as part of Teaching-Learning Process for Engineering Curriculum.

\section{References:}

1. ABET. Criteria for Accrediting Engineering programs, 2014-2015. From www.abet.org/eaccriteria-2014-2015.

2. Washington Accord. From www.ieagreements.org/washington-accord

3. National Board of Accreditation. From nbaind.org./En/1051/-nbas-accreditationparameters-criteria-\& processors.aspx

4. Writing and Assessing Course-level student learning outcome Texas Tech University from www.depts.ttu/opa.

5. Everton Systems from www.classontheweb.com

6. Alliance \& Meyer Luskin Academy from www.luskinacademy.org

7. Developing a Computer Science - Specific Learning Taxonomy by Ursula Fuller and others from www.depts.ttu.edu/opa.

\section{Authors Profile}

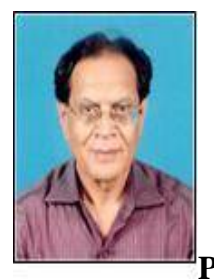

Prof K.L Chugh is working as Dean Computer Science in MLR Institute of Technology, Hyderabad with interest in Software Engineering, Software Manual Testing, Software Automated Testing, Computer Architectural implementation and Design patterns. He worked in Ministry of Defense in Production and Quality Assurance for 34 years. He has a total of 12 years of research experience in Software Testing Methodologies. He is contributing towards research by editing and reviewing multiple papers from various researchers. $\mathrm{He}$ is also working as a mentor for Innovation Center at MLRIT.

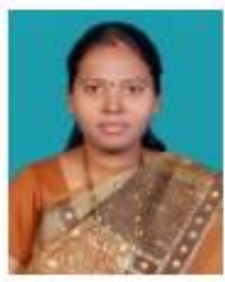

B. Madhuravani, Department of CSE, MLR Institute of Technology, Dundigal, Hyderabad. Working as Principal Investigator under DST Projects Women Scientist Scheme (WOS-A). She is doing Ph. D in Computer Science \& Engineering, JNTUH. Published 18 research papers in National and International Journal/Conferences. Her research interests include Information Security, Computer Networks, Distributed Systems and Data Structur 